\title{
Linguistic Intelligence and Critical Thinking amongst Students of the Inland Water and Ferries Transport Polytechnic of Palembang
}

\author{
Bambang Setiawan*, Umi Dian Adhitya Wulan Ningrum, Dani Dwi Sasongko
}

Corresponding Author:

Bambang Setiawan

bambang@poltektranssdp-

palembang.ac.id

Published: 12 January 2021

Publishing services provided by

Knowledge E

(c) Bambang Setiawan et al. This article is distributed under the

terms of the

Attribution License, which

permits unrestricted use and redistribution provided that the original author and source are credited.

Selection and Peer-review under the responsibility of the IWPOSPA Conference Committee.

\section{Abstract}

This study investigates the students' Linguistic Intelligence (LI) and Critical Thinking (CT) as Higher Order of Thinking Skills (HOTS) in the acquisition of English as a foreign language. 70 participants of Inland Water and Ferries Transport Polytechnic of Palembang took part in the current study. To measure the participants' linguistic intelligence scores, the researchers used the Thomas Armstrong Intelligence Test derived from Howard Gardner's MI Model. The instrument consists of 20 Likert type questions, for each of which 4 options are included. When testing participants' critical thinking, they used the scheme and the measures that trail after the WatsonGlaser Critical Thinking Appraisal. This test consists of five parts that are inferences, assumptions, deductions, interpreting information, and arguments. The results indicated that $11.43 \%$ of students displayed below average performances and $58.57 \%$ displayed high linguistic intelligence.

Keywords: Linguistic Intelligence; Critical Thinking; Language Acquisition.

\section{Introduction}

Language knowledgeable individuals enjoy and are skilled with words. They love to read, write, and learn languages. They also sound to teach others and describe things. There are eight different kinds of intelligence, one of which is linguistic. This intelligence involves the ability to efficiently use language as a means of reminiscence, rhetorically, or poetically. Linguistic intelligence also means speaking and understanding its language, one's native language, and perhaps other languages. Moreover, those with a high level of language intelligence represent a facility with languages and words. They usually read, write, tell stories, and store words with dates excellently. This intelligence is in line with higher order of thinking skill, that is critical thinking.

The main aim or goal of education is that the learners learn how to think. Learners need higher order of thinking skills that can help them to make reliable decisions 
and acquire new knowledge quickly, especially in English language learning. Basically critical thinking is categorized into Higher Order of Thinking Skills (HOTS). (King F.J., Goodson, L and Rohani, F. (2009). Higher Order Thinking Skills. Florida: Florida State University Press)

Previous study entitles The Relationship between Critical Thinking and Language Proficiency of Malaysian Undergraduates was conducted to find out the critical thinking ability of Malaysian undergraduates and its relationship with their language proficiency. (Rashid, R.A. and Hasyim, R.A. (2008). The Relationship between Critical Thinking and Language Proficiency of Malaysian Undergraduates. Edu-COM 2008 International Conference. pp. 373-384) It was conducted at Utara Malaysia University and was assigned 280 undergraduates. A demographic questionnaire and a test were used in the study. The demographical questionnaire was intended to gather and compile the language ability knowledge of undergraduates from the Sijil Pelajaran Malaysia (SPM) and Malaysian University English language Test (MUET); then the test (Bahasa Malaysia version of the Cornell Critical Thinking Test Level X) was used to find out the undergraduates' critical thinking. Pearson product-moment correlation was used in the data analysis of the study. Based on the study results, a significant relationship between the critical thinking skills of undergraduates and language skills has emerged.

Furthermore, derived from personal experience of one of the writers as an instructor of Language Unit of English at Inland Water and Ferries Transport Polytechnic of Palembang while she involved in instructing the students in running the daily speech activity. In a past year, from the routine activity of language unit, she recognized that student's ability in delivering speech was unsatisfactory. Some of students were not able to differentiate to pronounce definite article "the" when it is followed by a vocal or consonant sound. When they wrote an opening of "The honorable", they missed the rule how to pronounce it. Although not many of them do that. However, the writer also conducts an informal interview with another lecturer whom also become the instructor. From the interview, she noticed that another lecturer found that matter was happening the same way too.

Depart from Rashid's study and one of writer's personal experience, the writers are interesting to conduct a research not only to find out students' critical thinking, but also broadening the scope to also find out students' linguistic intelligence, limited to 2nd level students of Inland Water and Ferries Transport Polytechnic of Palembang? 


\section{Research Methods}

This study is included in quantitative research as it uses a testing tool to generate the mastery score of the subject in summary. The approaches to data processing (mixed methods) are quantitative and qualitative. Quantitative data were analyzed employing simple descriptive statistics, while qualitative statistics clarified the students' cognitive levels.

\section{Results and Discussion}

To measure the participants' linguistic intelligence scores, the researchers use Thomas Armstrong Intelligence Test. (Armstrong, T. (2009). Multiple Intelligences in the Classroom: 3rd Edition. Virginia: ASDC) It derived from Howard Gardner's MI Model. (Gardner, H. (2005). Intelligence Reframed;Multiple Intelligences for The 21 First Century. New York: Basic Books) The instrument consists of 20 Likert type questions, for each of which 4 options are considered questionnaire. The schemes and the test requirements of this test follow and are related to the Watson-Glaser critical thinking appraisal in assessing the participants' critical thinking. (Watson, G, and Glaser, E.M. (2012). WatsonGlaser $^{\mathrm{TM}}$ User Guide and Technical Manual UK Supervised and Unsupervised Versions. UK: Pearson Education Inc) Five parts of this test are inferences, assumptions, assumptions, information interpretation, and arguments. The instrument test are presented in table 1 as follows.

\subsection{Population and Sample}

The population refers to the group where the researcher aims to generalize the study outcome results or the broader group to which the studies are aimed. (Fraenkel, J.R., Wallen, N.E., and Hyun, H.H. (2012). How to Design and Evaluate Research in Education. New York: McGraw-Hill Companies, Inc., 129)

The 2nd level students of Inland Water and Ferries Transport Polytechnic of Palembang in the academic year of 2019/2020 become the population of the study. The total population is 137 students from Inland Waterways classes.

As mentioned before, the writers are having 2 nd level classes as the population of the study. Every class has a chance to be taken as a sample of the population in this study. If subject is less than 100, it is better to take all subjects, but if the subject is a big population (more than 100), the researcher can take them between $10-15 \%$ or $20-25 \%$ 
TABLE 1: Instrument Test Specifications

\begin{tabular}{|c|c|c|c|}
\hline Variable & Indicators & Test Number & $\begin{array}{c}\text { Total of test } \\
\text { item }\end{array}$ \\
\hline \multirow[t]{6}{*}{ Linguistic Intelligence } & 1. Considering that books are important & $1-20$ & 20 \\
\hline & $\begin{array}{l}\text { 2. Claiming that learning English, social } \\
\text { science, and history at school is easier than } \\
\text { mathe- matics and natural science }\end{array}$ & & \\
\hline & $\begin{array}{l}\text { 3. Spelling words accurately and enjoying } \\
\text { words games }\end{array}$ & & \\
\hline & 4. Enjoying debate and discussion & & \\
\hline & 5. Producing writing that better than peers & & \\
\hline & $\begin{array}{l}\text { 6. Communicating with people in a highly } \\
\text { verbal way }\end{array}$ & & \\
\hline \multirow[t]{5}{*}{ Critical Thinking } & 1. Analyzing inferences & $1,2,3,4$ & 4 \\
\hline & 2. Analyzing assumptions & $5,6,7,8$ & 4 \\
\hline & 3. Analyzing deductions & $9,10,11$ & 3 \\
\hline & 4. Interpreting information & $12,13,14$ & 3 \\
\hline & 5. Evaluating arguments & $15,16,17$ & 3 \\
\hline \multicolumn{3}{|l|}{ TOTAL } & 40 \\
\hline
\end{tabular}

or more to be the sample. (Arikunto, S. (2012). Prosedur Penelitian Suatu Pendekatan Praktek, Edisi Revisi 2010. Jakarta: Rineka Cipta)

In line with the statement above, from five classes of total population, multiple students took part in the research as a sample. They are assigned using a systemic nonrandom sampling technique as a sample for this analysis. Every n-th individual is picked for inclusion in the sample during systematic sampling in the population list. (Frankel et al, Op.Cit., 97) Each second person is selected in this case from the population list.So the writers got a total number of 70 students as sample or around $51,09 \%$.

\subsection{Data Collection}

Prior to data collection, the researchers firstly obtain a letter of consent No. UM.002/6/16 Poltektrans SDP - 2020 from the Director of Inland Water and Ferries Transport Polytechnic of Palembang to conduct this study. The data collection is conducted on July, 4th, 2020, It is listed sequentially as follows:

\section{Test of Critical Thinking}

(a) First, the identification of participants, including the name of the student, the student's register number (NPT / Nomor Pokok Taruna), class, and the signature of the student, is included. They are required to fill out the attendance list representing the identity of these participants; 
(b) Secondly, after participants are already done writing their identity on the participation list, they are told of the directions relevant to the critical thinking test and, when ready for the test, the researcher begins the testing process and watches the test site;

(c) All problems consist of 17 points relating to critical thinking in the response sheet presented for about 50 minutes is answered by the participants.

(d) After completing the exam, the researcher evaluate their response sheets and analyze the result;

2. Questionnaire of Linguistic Intelligence

(a) The questionnaire of linguistic intelligence is carried out after the participants had already finished doing the critical thinking test;

(b) The procedures to perform the linguistic intelligence questionnaire are explained by the researcher before participants fill out the questionnaire;

(c) The participants must answer all 20 items related to critical thinking on the response sheet provided in about 15 minutes;

(d) After this test, the participants are evaluated, and their responses analyze through their response sheets.

\subsection{Validity}

Validity is the extent to which inferences made from assessment result should be appropriate, meaningful, correct, and useful. (Ibid., 148) Whilst Sugiyono claims that valid means the instrument which is used in the research can be used to measure what should be measured. (Sugiyono. (2012). Metode Penelitian Kuantitatif, Kualitatif dan R\&D. Bandung: Alfabeta) Validity test is the degree to which a test measures what it is supposed to measure, or it can be used succesfully for the purposes for which it is intended.

Furthermore, the validity of each item in test and questionnaire is analyzed by using Pearson Product Moment Correlation. The result of the calculation is compared to the rtable. The test item is valid if $r_{\text {count }}>r_{\text {table. }}$.

\subsection{Validity of Critical Thinking Appraisal}

In line with the SPSS result of analyzing the validity of critical thinking test, it was found that all test items were valid. The result is claimed to be valid if $r_{\text {count }}>r_{\text {table }}$. In this case, 
since $\mathrm{N}=70$ then the value of $\mathrm{df}=\mathrm{N}-2=70-2=68$, so the value of $\mathrm{r}_{\text {table }}$ at $\mathrm{df}=$ 68 is 0.235. (Ghozali, I. (2014). Ekonometrika Teori, Konsep dan Aplikasi dengan IBM SPSS 22. Semarang: Badan Penerbit Universitas Diponegoro) The result as presented in Table 3 indicates that all the test items are valid because the value of $r_{\text {count }}>0.235$.

TABLE 2: Case Processing Summary of Critical Thinking Test

\begin{tabular}{|c|c|c|c|}
\hline \multicolumn{4}{|c|}{ Case Processing Summary } \\
\hline & & $\mathrm{N}$ & $\%$ \\
\hline \multirow[t]{3}{*}{ Cases } & Valid & 70 & 100.0 \\
\hline & Excluded $^{a}$ & 0 & .0 \\
\hline & Total & 70 & 100.0 \\
\hline
\end{tabular}

a. Listwise deletion based on all variables in the procedure.

TABLE 3: Validity of Critical Thinking Test

\begin{tabular}{|c|c|c|c|c|c|}
\hline \multicolumn{6}{|c|}{ Item-Total Statistics } \\
\hline & $\begin{array}{l}\text { Scale Mean if } \\
\text { Item Deleted }\end{array}$ & $\begin{array}{c}\text { Scale } \\
\text { Variance if } \\
\text { Item Deleted }\end{array}$ & r Count & r Table & $\begin{array}{c}\text { Cronbach's } \\
\text { Alpha if Item } \\
\text { Deleted }\end{array}$ \\
\hline Item1 & 19.7500 & 41.850 & .420 & .235 & .692 \\
\hline Item2 & 19.7500 & 41.964 & .399 & .235 & .693 \\
\hline Item3 & 20.0556 & 42.397 & .371 & .235 & .698 \\
\hline Item4 & 20.1111 & 42.444 & .370 & .235 & .698 \\
\hline Item5 & 20.1389 & 41.609 & .411 & .235 & .691 \\
\hline Item6 & 20.1389 & 42.066 & .336 & .235 & .695 \\
\hline Item7 & 20.0278 & 41.971 & .336 & .235 & .694 \\
\hline Item8 & 19.7500 & 41.736 & .441 & .235 & .691 \\
\hline Item9 & 19.7500 & 41.736 & .441 & .235 & .691 \\
\hline Item10 & 20.0278 & 41.971 & .336 & .235 & .694 \\
\hline Item11 & 19.7500 & 41.736 & .441 & .235 & .691 \\
\hline Item12 & 20.0556 & 42.397 & .371 & .235 & .698 \\
\hline Item13 & 19.7500 & 41.850 & .420 & .235 & .692 \\
\hline Item14 & 20.0000 & 41.771 & .366 & .235 & .693 \\
\hline Item15 & 19.6667 & 42.343 & .395 & .235 & .695 \\
\hline Item16 & 19.7222 & 42.435 & .331 & .235 & .696 \\
\hline Item17 & 19.8056 & 42.275 & .338 & .235 & .696 \\
\hline
\end{tabular}

\subsection{Validity of Linguistic Intelligence Questionnaire}

In relation to the SPSS result of analyzing the validity of linguistic intelligence questionnaire, it was found that all test statements were valid. The result is claimed to be valid 
if $r_{\text {count }}>r_{\text {table. }}$. The result as presented in Table 5 indicates that all the test statements are valid because the value of $r_{\text {count }}>0.235$.

TABLE 4: Case Processing Summary of Linguistic Intelligence Questionnaire

\begin{tabular}{l|c|c|c|}
\hline Case Processing Summary & & & \\
& & N & $\%$ \\
\hline Cases & Valid & 70 & 100.0 \\
\hline & Excluded $^{a}$ & 0 & .0 \\
\hline & Total & 70 & 100.0 \\
\hline
\end{tabular}

a. Listwise deletion based on all variables in the procedure.

TABLE 5: Validity of Linguistic Intelligence Questionnaire

\begin{tabular}{|c|c|c|c|c|c|}
\hline \multicolumn{6}{|c|}{ Item-Total Statistics } \\
\hline & $\begin{array}{l}\text { Scale Mean if } \\
\text { Item Deleted }\end{array}$ & $\begin{array}{c}\text { Scale } \\
\text { Variance if } \\
\text { Item Deleted }\end{array}$ & r Count & r Table & $\begin{array}{c}\text { Cronbach's } \\
\text { Alpha if Item } \\
\text { Deleted }\end{array}$ \\
\hline Item1 & 116.5556 & 333.740 & .840 & .235 & .753 \\
\hline Item2 & 116.0000 & 328.857 & .757 & .235 & .749 \\
\hline Item3 & 115.9444 & 331.654 & .716 & .235 & .752 \\
\hline Item4 & 116.5278 & 334.828 & .802 & .235 & .754 \\
\hline Item5 & 116.4167 & 335.050 & .611 & .235 & .755 \\
\hline Item6 & 116.5278 & 334.942 & .795 & .235 & .754 \\
\hline Item7 & 116.1667 & 333.400 & .702 & .235 & .753 \\
\hline Item8 & 116.4722 & 337.913 & .676 & .235 & .757 \\
\hline Item9 & 116.0556 & 326.683 & .818 & 235 & .747 \\
\hline Item10 & 116.5278 & 334.942 & .795 & .235 & .754 \\
\hline Item11 & 116.0556 & 325.883 & .849 & .235 & .747 \\
\hline Item12 & 116.5556 & 333.625 & .846 & .235 & .753 \\
\hline Item13 & 116.1667 & 333.400 & .702 & .235 & .753 \\
\hline Item14 & 116.5556 & 333.740 & .840 & .235 & .753 \\
\hline Item15 & 115.9722 & 330.828 & .713 & .235 & .751 \\
\hline Item16 & 116.1667 & 333.286 & .707 & .235 & .753 \\
\hline Item17 & 116.2500 & 328.536 & .700 & .235 & .749 \\
\hline Item18 & 116.4722 & 337.913 & .676 & .235 & .757 \\
\hline Item19 & 116.0000 & 328.743 & .761 & .235 & .749 \\
\hline Item20 & 116.5278 & 335.113 & .598 & .235 & .755 \\
\hline
\end{tabular}

\subsection{Reliability}

A useful study purpose is to provide reliable measurements or findings. Reliability implies that instrument scores are accurate and consistent. (Creswell, J.W. (2012). 
Educational Research: Planning, Conducting, and Evaluating Quantitative and Qualitative Research 4th Edition. Upper Saddle River, NJ: Merrill) Reliability is explained as a zero-to-one coefficient. The nearest the reliability coefficient to 1.00 , the reliable the measurement, and the lower the measurement measuring error. When tests are used in employment contexts reliabilities above 0.89 are generally considered excellent, 0.80 - 0.89 good, and $0.70-0.79$ adequate. Values below 0.70 suggest the test may have limited applicability. A standard value of 0.60 indicates $60 \%$ consistency in the scores that are produced by the instrument.

Then, Cronbach Alpha with an assistance of SPSS 22 is used to calculate the reliability of the critical thinking and linguistic intelligence instruments from an examination of internal consistency of the test.

\subsection{Reliability of Critical Thinking Appraisal}

In line with the SPSS result of analyzing the reliability of critical thinking test, it was found that the test instrument was reliable as shown Table 6.

TABLE 6

\begin{tabular}{|l|c|}
\multicolumn{3}{c}{ Reliability of Critical Thinking Test } \\
\hline Cronbach's Alpha & N of Items \\
\hline 706 & 17 \\
\hline
\end{tabular}

The result is claimed to be reliable if the value of Cronbach's Alpha is higher than standard value 0.60. Table 6 shows that the Cronbach's Alpha value is $0.706>0.60$. Therefore, the tests are reliable.

\subsection{Reliability of Linguistic Intelligence Questionnaire}

In relation to the SPSS result of analyzing the reliability of linguistic intelligence questionnaire, it was found that the test instrument was reliable as shown Table 7.

TABLE 7

\begin{tabular}{|c|c|}
\hline \multicolumn{2}{|c|}{ Reliability of Linguistic Intelligence Questionnaire } \\
\hline Cronbach's Alpha & $\mathrm{N}$ of Items \\
\hline .764 & 20 \\
\hline
\end{tabular}

The result is claimed to be reliable if the value of Cronbach's Alpha is higher than standard value 0.60. Table 7 shows that the Cronbach's Alpha value is $0.764>0.60$. Therefore, the tests are reliable. 
The critical thinking performance of the 2 nd level students of Inland Water and Ferries Transport Polytechnic of Palembang is calculated by measuring the number of the right responses in the critical thinking assessment shown in Figure $1 .$.

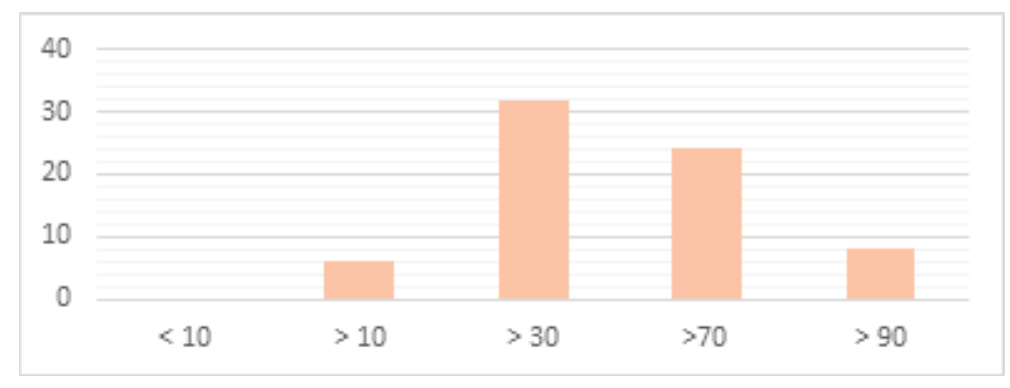

Figure 1: Students' Critical Thinking

In accordance with the score obtained from student's critical thinking test, the writer found that there are eight students who gain score $>90$, twenty-four students who gain score $>70$, thirty-two students who gain score $>30$, and six students who gain score $>10$. Table 8 described the complete result of data description of students' critical thinking. The performance categorizations are follow and related to the Watson-Glaser Critical Thinking Appraisal. (Watson et al. Op Cit., 11)

TABLE 8: The Score Summary of Student's Critical Thinking

\begin{tabular}{|l|c|c|c|c|}
\hline No. & Performance & Score & Frequency & Percentage \\
\hline 1. & Well above average & 91 and above & 8 & $11.43 \%$ \\
\hline 2. & Above average & $71-90$ & 24 & $34.28 \%$ \\
\hline 3. & Average & $31-70$ & 32 & $45.71 \%$ \\
\hline 4. & Below average & $11-30$ & 6 & $8.57 \%$ \\
\hline 5. & Well below average & Below 10 & 0 & 0 \\
\hline
\end{tabular}

Furthermore, student's linguistic intelligence is determined by calculating total number of responses in the linguistic intelligence questionnaire which illustrated in Figure 2.

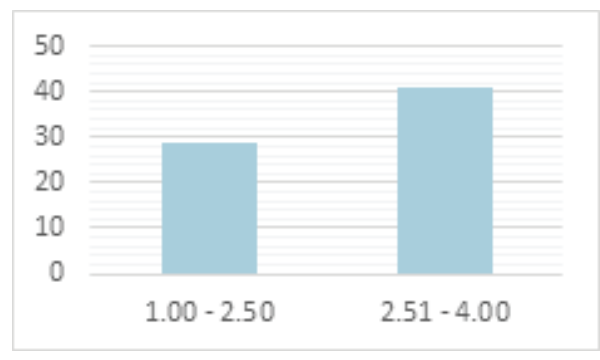

Figure 2: Students' Linguistic Intelligence

In accordance with the total number of responses from student's linguistic intelligence questionnaire, the writer found that there are twenty-nine students who gain score 
under the investment from 1.00 to 2.50 and forty-one students who gain score under the investment from 2.51 to 4.00 .

In analyzing the questionnaire result of student's linguistic intelligence, the writer used Armstrong Linguistic Intelligence Inventory. (Armstrong, T. Op Cit., 22) There were 20 questions, for each of which 4 options are considered. The options are 1 for strongly disagree, 2 for disagree, 3 for agree, and 4 for strongly disagree. The minimum score is 1 if student's response is entirely 1 , and the maximum score is 4 if student's response is entirely 4 . The result of the test was categorized as follows:

1. The student who gains score under the investment from 1.00 to 2.50 was determined as low intelligence of linguistic.

2. The student who gains score under the investment from 2.51 to 4.00 was determined as high intelligence of linguistic.

Table 9 described the complete result of data description of students' linguistic intelligence.

TABLE 9: The Score Summary of Student's Linguistic Intelligence

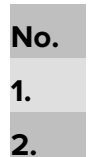

No.

2.

\begin{tabular}{|c|}
\hline Score \\
\hline $2.51-4.00$ \\
$1.00-2.50$ \\
\hline
\end{tabular}

\begin{tabular}{|c|}
\hline Frequency \\
\hline 41 \\
29 \\
\hline
\end{tabular}

Percentage $58.57 \%$

$41.42 \%$

\section{Conclusion}

In relation to the results and discussion described in the previous, it is concluded that there were 8.57 percent students who are in the performance of below average and 41.42 percent who are categorized into low linguistic intelligence. Even though the figure is relatively low, it must become a serious concern for the teacher and/or instructor to improve it and do some treatments, and from the percentage contribution as stated in the conclusion, the teacher and/or instructor of language unit of Inland Water and Ferries Transport Polytechnic of Palembang are suggested to design more interactive as well as exciting courses that not only enable students to develop their speech skills but also to explore and develop their critical thinking skills by, for example, using the correct written material, reasoning, and argument, will encourage them to talk remarkably. Then, to develop students' linguistic intelligence, the teacher and/or instructor can support them by encouraging them to enjoy real communicating through speaking and also applying other skills all at once. This allows students to see the purpose of language, and helps 
them take an interest in it and also to cope with it in their real life. However, more studies will provide more evidence for generalization.

\section{References}

[1] Arikunto, S. (2012). Prosedur Penelitian Suatu Pendekatan Praktek, Edisi Revisi 2010. Jakarta: Rineka Cipta.

[2] Armstrong, T. (1999). 7 Kinds of Smart: Identifying and Developing Your Multiple Intelligences. New York: Plume.

[3] Armstrong, T. (2009). Multiple Intelligences in the Classroom ( $3^{\text {rd }}$ ed.). Virginia: ASDC.

[4] Armstrong, T. (2014). You're Smarter than You Think: A Kid's Guide to Multiple Intelligence. Minneapolis: Free Spirit Publishing Inc.

[5] Basrowi and Soenyono (National Researcher). (2007). Metode Analisis Data Sosial. Kediri: Jenggala Pustaka Utama.

[6] Best, J. W. and Kahn, J. V. (2005). Research in Education ed.9th. New Delhi: Prentice Hall of India Ltd.

[7] Brown, H. D. (2004). Language Assessment:Principles and Classroom Practices. NY: Pearson Education Inc.

[8] Caplan, D. (2006). Why is Broca's Area Involved in Syntax?. Cortex, vol. 42, issue 4, pp. 469-471.

[9] Chaffee, J. (2015). Critical Thinking, Thoughtful Writing (6 ${ }^{\text {th }}$ ed.). Boston: Houghton Mifflin Company.

[10] Chance, P. (1986). Thinking in the Classroom: A Survey of Programs. USA: Mishavaku.

[11] Changwong, K., Sukkamart, A. and Sisan, B. (2018). Critical thinking skill development: Analysis of a new learning management model for Thai high schools. Journal of International Studies, vol. 11, issue 2, pp. 37-48.

[12] Checkley, K. (1997). The First Seven and the Eighth: A conversation with Howard Gardner. Educational Leadership, vol. 55, issue 1, pp. 8-13.

[13] Cohen, L. and Manion, L. (1994). Research Methods in Education (4 ${ }^{\text {th }}$ ed.). London: Routledge.

[14] Cottrell, S. (2005). Critical Thinking Skills: Developing Effective Analysis and Argument. New York: Palgrave MacMillan.

[15] Creswell, J. W. (2012). Educational Research: Planning, Conducting, and Evaluating Quantitative and Qualitative Research 4th Edition. Upper Saddle River: Merrill.

[16] Dewey, J. (1933). How We Think. New York: Heath. 
[17] Fraenkel, J. R. and Wallen, N. E. (2000). How to Design and Evaluate Research in Education (4 $4^{\text {th }}$ ed.). Boston: McGraw-Hill.

[18] Fraenkel, J. R., Wallen, N. E. and Hyun, H. H. (2012). How to Design and Evaluate Research in Education. New York: McGraw-Hill Companies, Inc.

[19] Fromkin, V., Rodman, R. and Hyams, N. (2013). An Introduction to Language $\left(10^{\text {th }}\right.$ ed.). USA: Wadsworth Cengage Learning.

[20] Gardner, H. (1993). Multiple Intelligences. New York: Basic Books.

[21] Gardner, H. (2005). Intelligence Reframed; Multiple Intelligences for the $21^{\text {st }}$ Century. New York: Basic Books.

[22] Ghozali, I. (2014). Ekonometrika Teori, Konsep dan Aplikasi dengan IBM SPSS 22. Semarang: Badan Penerbit Universitas Diponegoro.

[23] Harmer, J. (1996). The Practice of English Language Teaching. New York: Longman Publishing.

[24] Higgins, J. (2005). The Radical Statistician. California: Ed. D Copyright.

[25] Jacobs, H. L., et al. (1981). Testing ESL composition: A Practical Approach (Electronic Version). Rowley: Newbury House, pp. 91-104.

[26] Karakoc, M. (2016). The Significance of Critical Thinking Ability in Terms of Education. International Journal of Humanities and Social Science, vol. 6, issue 7, p.543

[27] King, F. J., Goodson, L. and Rohani, F. (2009). Higher Order Thinking Skills. Florida: Florida State University Press.

[28] Kuebli, J. E., Harvey, R. D. and Korn, J. H. (2008). Critical Thinking in Critical Courses: Principles and Applications. In Dunn, D. S., Jane S. H., and Randolph, A. S. 350 Main Street, Malden, MA 02148-5020, USA 9600 Garsington Road, Oxford, OX4 2DQ, UK, The Atrium, Southern Gate, Chichester, West Sussex, PO19 8SQ, UKTeaching Critical Thinking in Psychology: A Handbook of Best Practices. Chichester: Wiley-Blackwell.

[29] Lazear, D. (1994). Seven Pathways of Learning: Teaching Students and Parents about Multiple Intelligences. Tucson: Zephyr Press.

[30] Moon, J. (2008). Critical Thinking of Theory and Practice. London: Library of Congress.

[31] Moore, B. N and Parker, R. (2007). Critical Thinking ( $8^{\text {th }}$ ed.). New York: The McGrawHill Companies Inc.

[32] Mousavi, S. A. (2002). An Encyclopedic Dictionary of Language Testing ( $3^{\text {rd }}$ ed.). Taiwan: Tung Hua Book Company.

[33] Murawski, L. M. (2014). Critical Thinking in the Classroom and Beyond. Journal of Learning in Higher Education, vol.10, issue 1, p. 543 
[34] Nicholson-Nelson, K. (1998). Developing Student's Multiple Intelligences. New York: Scholastic Professional Book.

[35] Paul, R. and Elder, L. (2014). The Miniature Guide to Critical Thinking: Concepts and Tools. Retrieved December 18, 2016 from www.criticalthinking.org.

[36] Punch, K. F. (1998). Introduction to Social Research: Quantitative and Qualitative Approaches. London: Sage.

[37] Rashid, R. A. and Hasyim, R. A. (2008). The Relationship between Critical Thinking and Language Proficiency of Malaysian Undergraduates. Presented at Edu-COM 2008 International Conference. Sustainability in Higher Education: Directions for Change,Edith Cowan University, Perth Western Australia, 19-21 November 2008. This Conference Proceeding is posted at Research Online. http://ro.ecu.edu.au/ceducom/ 36, p. 373-384.

[38] Richards, J. S. and Renandya, W. A. (2002). Methodology in Language Teaching, An Anthology of Current Practice. New York: Cambridge University Press.

[39] Ruggiero, V. R. (2012). Beyond Feelings: A Guide to Critical Thinking (9 $9^{\text {th }}$ ed.). New York: The McGraw-Hill Companies Inc.

[40] Sugiyono. (2012). Metode Penelitian Kuantitatif, Kualitatif dan R\&D. Bandung: Alfabeta.

[41] Washburn, P. (2010). The Vocabulary of Critical Thinking. New York: Oxford University Press Inc.

[42] Watson, G. and Glaser, E. M. (2012). Watson-Glaser ${ }^{T M}$ User Guide and Technical Manual UK Supervised and Unsupervised Versions. UK: Pearson Education Inc. 